\title{
Governance Quality Influence on the Volume of Money in Selected Countries
}

\author{
Parvaneh Salatin \\ Islamic Azad University, Tehran, Iran \\ Tahereh Jahani \\ Payame Noor University (PUN), Tehran, Iran
}

\begin{abstract}
The main purpose of this paper is to examine the effectiveness of governance quality on the volume of money in the group of selected countries with middle-income ${ }^{1}$ through using panel data. This paper adopts Random Effects model and Generalized Method of Moments (GMM) as its methodology. Furthermore, the most important factors influencing on the volume of money in the group of selected countries with middle-income have been identified by econometric method. The results of the estimation method with Random Effects and GMM models show that the governance quality has a significant negative effect on the changes of the volume of money in the group of selected countries with middle-income from 1996 to 2009. It is worth considering that the quality of governance in most of these countries lies within the lower level.
\end{abstract}

Keywords: good governance, volume of money, middle-income

\section{Introduction}

Governance is the technique to use the power in economic and social resource management in order to achieve sustainable development. Good governance is an opportunity for economic security achievement, business improvement, attraction of domestic and foreign investment by virtue of six criteria reviewed by the World Bank, namely control of corruption (CC), rule of law (RL), regulatory quality (RQ), government effectiveness (GE), political stability and absence of violence (PV), and voice and accountability (VA). The market is accepted as an ideal in good governance, but realizing the ideals of economy and market is dependent on a set of factors that will not be arise automatically rather the government and social relations have a duty to create them. In this view, the government intrinsically hinders neither the development nor the development agent.

The main problem for achieving economic development is the realization of good governance. On the other hand, money and capital market performance and the way of attraction and allocation of society's savings thereby have significant impacts on the economic development of every country. In developing countries where

Parvaneh Salatin, Department of Economics, Firoozkooh Branch, Islamic Azad University, Firoozkooh, Iran.

Tahereh Jahani, Department of Economics, Payame Noor University (PUN), Tehran, Iran.

Correspondence concerning this article should be addressed to Tahereh Jahani, Rajaai st., Rajaai 25 AV., Katalom, Ramsar, Mazandaran, P.O. Box 19395-3697, Tehran, Iran. Tel: +98 9113965312. E-mail: T64.jahani@ gmail.com.

${ }^{1}$ In this article, according to the World Bank definition, the selected group of middle-income countries include: Argentina, Barbados, Bolivia, Botswana, Brazil, Costa Rica, Dominican Republic, Croatia, Guatemala, Iran, Malaysia, Mexico, Peru, Philippines, Russia, Romania, Thailand, Tunisia, Turkey, Ukraine, Bulgaria, Venezuela, Colombia, Ecuador, Uruguay, Singapore, Azerbaijan, Egypt, Kuwait, and Jordan. 
the capital market is not wide and deep enough, money market is the mainstream to attract savings in order to achieve the financial cost of investments. In such a situation, an efficient money market has the ability to absorb a lot of savings. The main purpose of this article is to investigate the effectiveness of the quality of governance on changes in the volume of money in selected group of middle-income countries. The present study adopted Dynamic Panel Data (DPD) and Static Panel Data (SPD) model to examine the following research hypothesis: There was a significant negative relationship between changes in the volume of money and the quality of governance in selected countries.

This required data to support or reject the above hypothesis gathered from reports and statistics published by external data sources and international internet sites such as World Development Indicator (WDI). Then, after a review of the theoretical and research background, the structure of the proposed model was introduced and estimated. Eventually, conclusions and policy recommendations were offered.

\section{Theoretical Background}

Good governance is considered as one of the most important issues discussed in development literature. This issue enjoys a special status to establish and institutionalize civil society in policy regarding to the granting of aid, especially in developing countries. The issue of good governance was introduced to achieve sustainable human development emphasizing on eliminating poverty, creating jobs, sustaining livelihoods, protecting and regenerating the environment. In good governance, three main groups of the government, civil society, and the private sector participate in conducting activities, and sometimes it is far higher than usual participation. The correct communication and interaction provide the context of good governance in different sizes. Various definitions and features for good governance are presented by different individuals and international institutions. This paper considers the proposed definitions and features of World Bank as its basis. The World Bank defines governance as a method of power in economic and social resource management for achieving sustainable development (Boininger, Nelson, \& Sarwa, 1992). According to this definition, member countries should improve resource allocation mechanisms, processes of policy formulation, selection and implementation of them, and the relationship between citizens and government. The bank proposed the following three distinct factors:

- the shape of political regime;

- the process of exerting authority in economic and social resources management for development;

- the government capacity to design, develop, and implement policies and the executive duties.

Also, the World Bank defines good governance based on six features and assesses the status of good governance in different countries once every two years during the period from 1996 to 2002 and annually from 2002 on based on these proposed features. These features are as follows:

(1) VA - capturing perceptions of the extent to which a country's citizens are able to participate in selecting their government, as well as freedom of expression, association, and a free media.

(2) PV—capturing perceptions of the likelihood that the government will be destabilized or overthrown by unconstitutional or violent means, including politically-motivated violence and terrorism.

(3) GE - capturing perceptions of the quality of public services, the quality of the civil service and the degree of its independence from political pressures, the quality of policy formulation and implementation of them, and the credibility of the government's commitment in such policies.

(4) RQ - capturing ability perceptions of government to formulate and implement sound policies and regulations which permit and promote private sector development. 
(5) RL - capturing perceptions of the extent in which agents have confidence in and abide by the rules of society, and in particular the quality of contract enforcement, property rights, the police, and the courts, as well as the likelihood of crime and violence.

(6) $\mathrm{CC}$ - capturing perceptions of the extent to which public power is exercised for private interest, including both petty and grand forms of corruption, as well as capture of the state by elites and private interests.

In this definition, governance for achieving its community development is more appropriate. The more positive features, such as the RL, VA, and GE in a society are, the less corruption, political instability and violence, and additional regulation there would be. On the other hand, the World Bank believes that good governance is a kind of governance in which the public institutions act in a responsible, transparent, and accountable manner and in a way which will lead to poverty reduction and economic growth. From the bank's perspective, there are many reports that reveal the existence of bad governance which are known as the main reasons for the failure of the governments and undermining market operations. The World Bank has calculated statistics related to the various characteristics of good governance with approximation and error through utilization of standard unobserved components models. It should be noted that although these figures have some measurement errors and are approximate, they can show ranking of countries in terms of being poor, average, good, or critical.

The range of calculated indices is between 2.5 and -2.5 for most countries, and the more calculated index is close to 2.5, the more situation of that country is appropriate and vice versa (Kaufmann, Kraay, \& Mastruzzi, 2002, 2004, 2005, 2006a, 2006b, 2007a, 2007b, 2007c). It should be noted that the World Bank has not calculated numerical index for the governance quality, but this study considers simple arithmetic average of these six indicators as the index of governance quality based on the accomplished studies by Gani and Duncan (2004).

Evidence suggests that political instability as an indicator of good governance leads to changes in the volume of money and inflation regardless of the economic variables and the economic structure of various countries as well. In developing countries, the instability arises in political space, reduces investment, and creates incentive in capital flight and detriment of trade, and leads to a decrease in the rate of return or asset stopping (Dhonte \& Kapur, 1996). Political instability affects the production agents on the economic growth. Instability with an increased risk of capital loss reduces achievement of the physical investment and also increases the cost of capital utilization such as interest rates. As a result, domestic and foreign investments are reduced. On the other hand, the government's behavior is affected by instability because of the government's increasing military and welfare expenditures for reducing seizures on one hand, and the reduction in its revenues because of the reduction of economic activities on the other. Therefore, the volume of money and then inflation increase with increasing budget deficits (Dhaneshwar \& Hadjimichea, 1996).

The results of the economic research suggest that reforms which are done aiming at reducing political instability increased economic freedom and democracy, and this increase certainly helps to reduce inflation. Accordingly, another indicator of good governance is the corruption control that brings about qualitative and quantitative effects with itself. Financial corruption will decrease in the revenues and increase in government's expenditures which in turn leads to increases in the government budget deficit. If the budget deficit causes pressure on the monetary authorities for increasing the money supply in order to cover the budget deficit, it can increase the volume of money and inflation.

$\mathrm{RQ}$ refers to the portion where government policies increase or decrease the market activities which are 
measured in terms of two sub-indices, namely the strength of financial institutions and organizations as well as the market size. In this regard, the more explicit the rules are, the easier the enforcement of them is. Enforcement of laws will be more and more difficult with the multiplicity of rules as well as their complexity and will have deleterious consequences such as the development of corruption, bribery, and informal activities (Djankov, Caralee, Nenova, \& Shleifer, 2003).

Several studies show that the governments with the highest level of interference in national economy have the highest rules and regulations. The greater the number of laws and regulations are, the more prevention there would be, and finally, the bulkier and larger governmental structures are needed to add strength and growth to government expenditures and lead to rise at the level of GDP. In the repeated cycles, this process leads to an increase in the government deficit, the volume of money, and inflation.

One of the results of establishing good governance can be more independence of central banks in the adoption and implementation of monetary policy. Empirical studies generally confirm that developed countries succeeded in reducing inflation by using independent central banks as a means of reducing inflationary pressures through monetary policy. Some studies show that if monetary policy is delegated to an independent central bank, it reduces the scope of inflationary bias of monetary policy. Governments wish to simplify monetary policy in order to award credit through political pressure on monetary authorities; because monetary policy puts the financial status of the governments into an inappropriate position via loss of seignior age revenues and reduction in tax receipts due to a temporary recession in economy. When the central bank has the political independence, it can resist the government pressure in adopting the expansionary monetary policy which can increase the volume of money and inflation in the society (Gutiérrez, 2003).

According to Edwards and Tabellini's study (1992), economies with weak institutions cannot have an efficient tax system; so printing money is an important source of earning for them and this issue leads to increase in the volume of money and inflation. Gani and Doncan (2004) showed a methodology to construct good governance indicators. In their study, good governance was comprised of four main features that are as follows: the RL, the GE, the RQ, and the development and social progress. Each of these features was made up of different components. In that study, good governance was calculated by using the simple arithmetic average of the four main indices. Acemoglu and Robinson (2006) presented evidence that the institutions are an important element in explaining crises and growth. They believe that the reason for poor macroeconomic performance is the existence of inefficient institutions which leads to inappropriate macroeconomic policies. Also, countries with weak institutions and organizations not only have less economic growth but also have higher rates of inflation. Morita and Zaelke (2005) in a study have examined the relationship among the RL, good governance, and sustainable development which can be used as tools by the organization on the course of development. The study demonstrated that various organizations have tried to promote the RL and good governance, and it suggested that for achieving sustainable development, support and enforcement are needed. In recent years, many projects by various organizations have been conducted and considerable progress has been made. The paper showed that a significant portion of this failure was led by the lack of law enforcement or mismatched implemented rules with prescribed rules.

\section{Models Explanation}

This paper used equation (1) in order to study the effectiveness of governance on the volume of money in middle-income group of selected countries. 


$$
\mathrm{L}(\mathrm{DM} 2)_{i t}=\beta_{0}+\beta_{1} \mathrm{~L}(\mathrm{GDP})_{i t}+\beta_{2} \mathrm{GG}_{i t}+\beta_{3} \mathrm{OPEN}_{i t}+\beta_{4} \mathrm{ICT}_{i t}+\mathrm{U}_{i t}
$$

In the above function, where L(DM2) illustrates the Log of changes in the volume of money; L(GDP) is the Log of real per capita Gross Domestic Product; GG is the quality of governance; ICT is the number of the internet users as an indicator of Information and Communication Technology; OPEN shows the proportion of the sum of exports and imports to Gross Domestic Product as openness indicator; $\mathrm{U}$ is the error estimation as well as $i$ and $t$ respectively are country and time.

Before estimating the model, first, it is necessary to examine the stability of variables. For this purpose, the Pesaran and Shin Unit Root Test should be conducted on data that have been used in the model in Table 1 .

As it can be seen in Table 1, GG is stable in level, and LGDP, LDM2, and OPEN will be stable with 95 percent confidence intervals by getting one difference, and ICT will be stable with 95 percent confidence intervals by getting two differences. Therefore, the null hypothesis is rejected regarding the existing unit root. Thus, the stability of the data used in the model is confirmed before the estimation. Results of co-integration test in Table 2 also show that there is a long-run relationship among the variables used in the model.

Table 1

The Stability of Variables Investigated in Selected Countries

\begin{tabular}{|c|c|c|c|c|c|}
\hline Type of regression & $\mathrm{L}(\mathrm{DM} 2)$ & GG & OPEN & ICT & $\mathrm{L}(\mathrm{GDP})$ \\
\hline $\begin{array}{l}\text { Shin and Pesaran Unit Root Test in Level } \\
(P-\nabla \text { alue })\end{array}$ & - & - & - & 0.0000 & - \\
\hline $\begin{array}{l}\text { Shin and Pesaran Unit Root Test in 1.ST Difference } \\
(P-\nabla \text { alue })\end{array}$ & 0.0000 & - & 0.0000 & - & 0.0000 \\
\hline $\begin{array}{l}\text { Shin and Pesaran Unit Root Test in 2.NT Difference } \\
(P-\nabla \text { alue })\end{array}$ & - & 0.0000 & - & - & - \\
\hline Results & $\mathrm{I}(1)$ & $\mathrm{I}(2)$ & $\mathrm{I}(1)$ & $\mathrm{I}(0)$ & $\mathrm{I}(1)$ \\
\hline
\end{tabular}

Source: Calculating by using Eveiws.6.

Table 2

The Results of the Co-integration Test in Middle Income Group of Selected Countries

\begin{tabular}{llll}
\hline & Kao Residual Co-integration Test & \\
\hline L(DM2) & OPEN & GG & L(GDP) \\
& & $t$-statistic & Prob. \\
& & -3.132211 & 0.0009 \\
\hline
\end{tabular}

Source: Calculating by using Eveiws.6.

Then, in order to estimate equation (1) using static panel, it is necessary to determine the method of estimation for certain types of combined-cross data. Therefore, initially the $F$-statistic was used to determine the existence (or lack) of separate intercept for each country. Due to the amount of the $F$-statistic calculated in Table 2, the null hypothesis is rejected based on the Ordinary Least Squares method which should be used with a different intercept (fixed or random effects method) in the model. Then, to know which method is more suitable for estimating the model (fixed effects or random effects), Hausman test was applied. According to the numerical value of $X^{2}$ which was calculated in Table 3, the null hypothesis of the random effect cannot be ruled out. Hence, the random effect model is appropriate for estimation results of which were presented in Table 3. Besides estimation of model by using static panel, equation (1) is estimated by using the GMM and relying on 
dynamic panel models. GMM estimator was used widely, particularly in recent empirical studies of macroeconomic and financial studies. Making use of this method for model estimation has many benefits, for example, Beck, Levine, and Loayza (2000) recognized very convenient use of this estimator in order to eliminate the variance of time series data. Estimator GMM by calculating individual specific effects in model (that is done by entering the dependent variable with lag in model as explanatory variable) provides a better control on the endogenous for total explanatory variables. The estimation results using GMM were presented in Table 3. There are the more additional calculations in Table 4, 5, 6, 7, 8, and 9 in the following paper.

Table 3

The Estimation Results of the Impact of Governance Quality on Changes in the Volume of Money by Using Random Effects Model and GMM Method in the Group of Selected Countries During 1996-2009 Period

\begin{tabular}{lll}
\hline & Dependent variable: Log of variations in the volume of money \\
\hline & Random Effects Method & Generalized Method of Moments (GMM) \\
\hline Independent variables & Estimated coefficients & Estimated coefficients \\
\hline C & -14.326 & - \\
\hline GG $2(-1))$ & $(-2.744)$ & 0.130659 \\
\hline \multirow{2}{*}{ OPEN } & - & $(8.444)$ \\
\hline ICT & -0.277168 & -0.322590 \\
& $(-1.792103)$ & $(-5.041016)$ \\
\hline L(GDP) & 1.205018 & 1.899873 \\
& $(3.028547)$ & $(10.22903)$ \\
\hline$R^{2}$ & $2.61 \mathrm{E}-08$ & 0.339819 \\
F-statistic & $(4.783420)$ & $(10.22347)$ \\
\multirow{2}{*}{ Hausman-statistic } & 1.493201 & 0.464576 \\
Sargan test statistic & $(6.857906)$ & $(2.064684)$ \\
\hline
\end{tabular}

Note. The numbers in () show $t$-statistic. Source: Calculating by using Eveiws.6.

Table 4

Summary of the Results of the Panel EGLS (Cross-section Random Effects) Model Estimation for the Period 1998-2009

\begin{tabular}{ll}
\hline Independent variables & Coefficient \\
\hline \multirow{2}{*}{ ICT } & $2.61 \mathrm{E}-08$ \\
& $\{4.783420\}$ \\
\hline \multirow{2}{*}{ OPEN } & 1.2050 \\
& $\{3.028547\}$ \\
\hline \multirow{2}{*}{ GG } & -0.2772 \\
& $\{-1.792103\}$ \\
\hline \multirow{2}{*}{ (GDP) } & 1.4932 \\
& $\{6.857906\}$ \\
C & -14.3260 \\
\hline
\end{tabular}


Table 4 continued

\begin{tabular}{lll}
\hline Independent variables & Coefficient & \\
\hline Included observations & 250 & Unweighted statistics \\
& Weighted statistics & 0.3869 \\
$R$-squared & 0.5927 & \\
$F$-statistic & 34.8618 & \\
Prob. & $(0.0000)$ & 0.6573 \\
Durbin-Watson statistic & 1.0279 & 23.9905 \\
Mean Dependent variables & 2.5800 & \\
\hline
\end{tabular}

Note. The numbers in () show Prob. and numbers in \{\} show $t$-statistic. Source: Calculating by using Eveiws.6.

Table 5

Summary of the Results of Correlated Random Effects-Hausman Test

\begin{tabular}{lllll}
\hline Variables & Fixed & Random & Var(Diff.) & Prob. \\
\hline ICT & 0.0000 & 0.000000 & -0.000000 & NA \\
OPEN & 1.161731 & 1.205018 & 0.051978 & 0.8494 \\
GG & -0.281801 & -0.277168 & 0.003587 & 0.9383 \\
L(GDP) & 1.579007 & 1.493201 & 0.027209 & 0.6029 \\
\hline Included observations & 250 & & & \\
Cross-section Random & 0.0000 & & & \\
Prob. & $(1.0000)$ & & & \\
Chi-Sq. d.f. & 4 & & & \\
\hline
\end{tabular}

Source: Calculating by using Eveiws.6.

Table 6

Summary of the Results of Cross-section Random Effects Test Equation

\begin{tabular}{ll}
\hline Variables & Coefficient \\
\hline ICT & $2.59 \mathrm{E}-08$ \\
& $\{7.370084\}$ \\
\hline OPEN & 1.161731 \\
GG & $\{2.533345\}$ \\
\hline L(GDP) & -0.281801 \\
\hline C & $\{-1.699125\}$ \\
Included observations & 1.579007 \\
$R$-squared & $\{5.780490\}$ \\
$F$-statistic & -16.45972 \\
Akaike info Criterion & 250 \\
Schwarz Criterion & 0.986582 \\
Hannan-Quinn criterion & 96.66540 \\
Durbin-Watson statistic & $\{0.0000\}$ \\
Mean Dependent variables & 2.478010 \\
S.D. Dependent variables & 2.956928 \\
\hline
\end{tabular}

Note. The numbers in \{\} show $t$-statistic. Source: Calculating by using Eveiws.6. 
Table 7

Summary of the Results of Panel Generalized Method of Moments Model

\begin{tabular}{|c|c|}
\hline Variables & Coefficient \\
\hline \multirow{2}{*}{$\mathrm{L}(\mathrm{DM} 2(-1))$} & 0.130659 \\
\hline & $\{8.444021\}$ \\
\hline \multirow{2}{*}{ OPEN } & 1.899873 \\
\hline & $\{10.22903\}$ \\
\hline \multirow{2}{*}{$\mathrm{L}(\mathrm{GDP})$} & 0.464576 \\
\hline & $\{2.064684\}$ \\
\hline \multirow{2}{*}{ GG } & -0.322590 \\
\hline & $\{-5.041016\}$ \\
\hline \multirow{2}{*}{ ICT } & 0.339819 \\
\hline & $\{10.22347\}$ \\
\hline Total panel (unbalanced) observations & 236 \\
\hline Mean dependent variables & 0.171390 \\
\hline S.E. of regression & 0.820942 \\
\hline$J$-statistic & 22.58160 \\
\hline S.D. dependent variables & 0.724465 \\
\hline Sum Squared resid & 155.6814 \\
\hline Instrument rank & 32.0000 \\
\hline
\end{tabular}

Note. The numbers in \{\} show $t$-statistic. Source: Calculating by using Eveiws.6.

Table 8

Summary of the Results of Redundant Fixed Effects Tests

\begin{tabular}{lll}
\hline & $t$-statistic & d.f. \\
\hline Cross-section $F$ & 254.0659 & $(29,244)$ \\
Prob. & $(0.0000)$ & \\
\hline
\end{tabular}

Source: Calculating by Using Eveiws. 6

Table 9

Summary of the Results of Cross-section Fixed Effects Test Equation

\begin{tabular}{lll}
\hline Variable & Coefficient & \\
\hline ICT & $2.70 \mathrm{E}-08$ & \\
& $\{4.017898\}$ & \\
OPEN & 0.749187 & \\
& $\{4.064376\}$ & \\
GG & -0.049064 & \\
\hline L(GDP) & $\{-0.549863\}$ & Un weighted statistics \\
C & 1.280765 & 0.2672 \\
\hline & $\{12.36922\}$ & \\
$R$-squared & -9.130973 & 0.2854 \\
-statistic & Weighted statistics & \\
Prob. & 0.3588 & 23.9848 \\
Durbin-Watson stat & 38.1938 & \\
Mean dependent variables & $(0.0000)$ & \\
\hline
\end{tabular}

Note. The numbers in \{\} show $t$-statistic. Source: Calculating by using Eveiws.6. 


\section{Conclusions}

The current paper reviewed the influence of the quality of governance in changes of the amount of the volume of money in selected middle-income countries based on theoretical principles and empirical evidence. In so doing, firstly the proposed model was introduced and then was estimated by means of DPD and SPD. The results of estimating regression (1) in selected countries with middle-income by GMM and Random Effects method in Table 3 illustrate that:

- Quality of governance (the simple average of six features of good governance) has a meaningful and negative impact on the logarithm of the volume of money changes in selected middle-income countries. Therefore, the hypothesis of a significant relationship between quality of governance and changes in the volume of money cannot be rejected in the middle-income group of selected countries. Improvement in governance caused decline in the volume of money in selected middle-income countries.

- The proportion of the sum of exports and imports to GDP as an openness index has a positive and significant impact on the logarithm of the volume of money changes in middle-income selected countries. In spite of the large-scale economy for the effective market size, more capacity utilization in industry, increases in the rate of capital formation and technological change, and creation of competition in the international market export, the promotion policies, based on the theoretical principles, lead to higher level of total productivity in production factors by making division of labor and using advantages and thus causes rises in GDP and increases the volume of money.

- The number of internet users as indicator of information and communication technologies has a positive and significant effect on the logarithm of the volume of money changes in selected middle-income countries. Development infrastructures including ports, roads, airports, communications infrastructure (mail, telephone, Internet) and transportation, water supply, energy and raw natural materials, public and recreational places, and etc. will reduce costs of economic activities of the private sector and increase the rate of return on capital and thus increase economic growth rate and the volume of money. The effects of the internet and using electronic money transactions can facilitate fiscal transfers in the domestic and international levels, increase the efficiency of transactions, the development of new businesses, and the expansion of economic activity on the internet. Money supply has increased with the development of electronic money, thus, increased the volume of money.

- Per capita GDP has a positive and significant impact on the logarithmic changes of the volume of money in the group of middle income countries.

According to the results of this paper, the following suggestions are offered:

- increasing government oversight responsibility for proper implementation of legislation and the reduction of its executive tasks;

- central bank independence as one of the indicators of monetary stability;

- political and economic stability to prevent divestment and fall in the value of money and creation of astronomical inflation;

- implementation of the control inflation policies.

\section{References}

Acemoglu, D., \& Robinson, J. A. (2007). Economic origins of dictatorship and democracy. Cambridge University Press, 45(8), 227-238. 
Beck, T., Levine, R., \& Loayza, N. (2000). Financial intermediation and growth: Causality and causes. Journal of Monetary Economics, 12(46), 31-77.

Boininger, E., Nelson, J. M., \& Sarwar, K. L. (1992). Governance and development: Issues and constraints. Washington, D.C.: CQ Press.

Dhaneshwar, G., \& Hadjimichea, T. M. (1996). Growth in sub Saharan Africa (IMF Staff Papers-International Monetary Fund, pp. 605-634).

Dhonte, P., \& Kapur, I. (1996). Toward a market economy: Structures of governance (IMF Working Paper-International Monetary Fund, pp. 1-16).

Djankov, S., Caralee, M., Nenova, T., \& Shleifer, A. (2003). Who owns the media? Journal of Law and Economics, 46(2), 341-381.

Edwards, S., \& Tabellini, G. (1992). Explaining fiscal policies and inflation in developing countries. Journal of International Money and Finance, Elsevier, 10(1), 16-48.

Gani, A., \& Duncan, R. (2004). Fiji's governance index, Australian National University and the University of the South Pacific at the University of the South Pacific. Retrieved from http://www.usp.ac.fj/index.php? id=piasdg_downloads_gov

Gutiérrez, E. (2003). Inflation performance and constitutional central bank independence: Evidence from Latin America and the Caribbean (IMF Working Paper-International Monetary Fund).

Kaufmann, D., Kraay, A., \& Mastruzzi, M. (2002). Governance matters II: Updated indicators for 2000/01 (World Bank Policy Research Working Paper. Washington, D.C. (2772)).

Kaufmann, D., Kraay, A., \& Mastruzzi, M. (2004). Governance matters III: Governance indicators for 1996, 1998, 2000, and 2002. World Bank Economic Review, 18, 253-287.

Kaufmann, D., Kraay, A., \& Mastruzzi, M. (2005). Governance matters IV: Governance indicators for 1996-2004 (World Bank Policy Research Working Paper, Washington, D.C., pp. 3-30).

Kaufmann, D., Kraay, A., \& Mastruzzi, M. (2006a). Measuring governance using perceptions data. In S. R. Ackrman (Ed.), Handbook of economic corruption. New York: Edward Elgar.

Kaufmann, D., Kraay, A., \& Mastruzzi, M. (2006b). Governance matters V: Aggregate and individual governance indicators for 1996-2005 (World Bank Policy Research Working Paper, Washington, D.C. No. 4012.).

Kaufmann, D., Kraay, A., \& Mastruzzi, M. (2007a). The worldwide governance indicators project: Answering the critics (World Bank Policy Research Working Paper, Washington, D.C. No.4149).

Kaufmann, D., Kraay, A., \& Mastruzzi, M. (2007b). Growth and governance: A reply/rejoinder. Journal of Politics, 69(2), 555-562.

Kaufmann, D., Kraay, A., \& Mastruzzi, M. (2007c). Governance matters VI: Aggregate and individual governance indicators for 1996-2006 (World Bank Policy Research Working Paper, Washington, D.C. No.4280).

Morita, S., \& Zaelke, D. (2005). Rule of law, good governance and sustainable development. Institute for Governance \& Sustainable Development, 13(20), 15-23. 